\title{
Dos Poetas Iberoamericanos de Nuestro Tiempo
}

\section{Nicolás Guillén}

\begin{abstract}
A FRICA y España andan por sus venas. A él podrían aplicarse estos versos de Selva Márquez:
\end{abstract}

\author{
Ay! mulato \\ cual si en un cafetal \\ hubiera nacido de pronto \\ una vara de nardo!
}

No sólo es Nicolás Guillén quien con más originalidad, intensidad y pureza ha poemizado los motivos negros de Cuba; es asimismo uno de los mayores poetas de América. Nacido en 1904 en Camagüey, este cubano realizó estudios de derecho en la Universidad de la Habana. Su poesía posee, dentro de esa perfecta unidad, una gran riqueza temática, armonizando su fuerte dramatismo con una ironía fina y penetrante. Se ha dicho más de una vez que lo característico de su lirismo no es sino una equivalencia del "son". Un paisano suyo, Marcelino Azoranena, poeta de raza negra, ha afirmado que "el son andaba silvestre, elemental, sin bridas, y que un día Guillén lo adiestró en octosílabos". A esta fase de su obra pertenecen aquellos versos suyos que se expresan en lenguaje típico negro. Por ejemplo:

$$
\begin{aligned}
& \text { Ayer me dijeron negro } \\
& \text { pa que me fajara yo: } \\
& \text { pero é que me lo desía } \\
& \text { era un negro como yo. }
\end{aligned}
$$


Tan blanco como te be y tu abuela sé quién é.

Sácala de la cosina, sácala de la cosina, mamá Iné.

Mamá Iné, tú bien lo sabe, mamá Iné, yo bien lo sé; mamá Iné te llama nieto, mamá Iné.

En otras breves canciones, el poeta ha sabido captar y trasmitir igualmente la sencillez, la gracia, la armonía y la sugerencia de los monótonos e insistentes ritmos del "son", sin necesidad de expresarse en típico lenguaje negro. $\mathrm{Y}$ uno de sus mayores poemas, el "Velorio de Papá Montero" -demasiado extenso para reproducirlo aquí-, es de los más bellos y hondos romances escritos en nuestro idioma, de una magnífica imaginería, de una sabia estilización, de una sensibilidad profundisima.

Lo que, a nuestro juicio, da mayor humanidad y valor a la obra de Guillén es su mensaje reivindicador, su sentido candentemente social. El ha sentido como pocos el problema del negro, problema auténticamente americano. Y lo ha expresado de la manera más convincente: con su palabra lírica, cuya apariencia un tanto naive no es sino el producto de una clarificación buscada y lograda. Ese sentido social se amplía, deja el tema negro y va a horizontes universales. Así, "Fusilamiento":

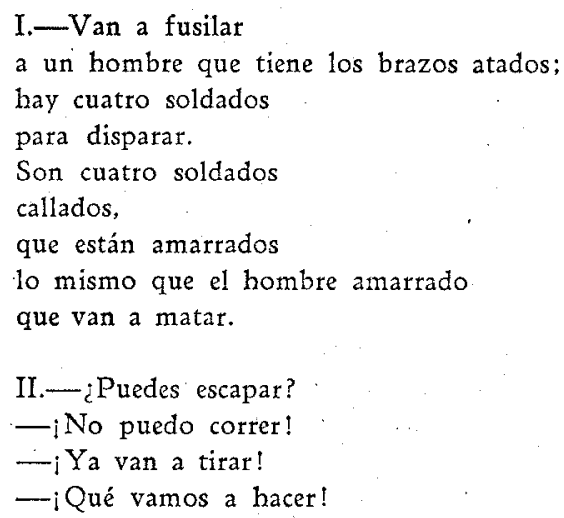




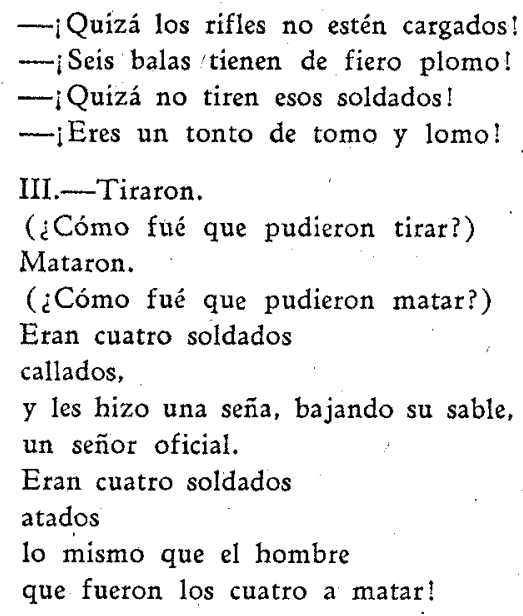

A la tónica de este poema pertenecen muchas de las más difundidas y celebradas páginas de Guillén: "No sé por qué piensas tú", "Dos niños", "Soldado muerto", "Cantaliso en un bar", "Caña", "Visita a un solar", "Sabás", "Canción del bongó."

Ciertamente, muchos poetas cultivaron y cultivan en Cuba la poesía negra. En un tiempo, Emilio Ballagas pareció ser el que lograría hermanarse a Guillén. Ballagas viró luego a otros rumbos líricos: su poesía actual responde a modalidades eminentemente subjetivas, sobrerrealistas muy a menudo. Guillén sigue siendo el gran poeta negro de Cuba. $Y$ lo es, atu en aquellos poemas en que no desenvuelve el problema de sus gentes (olvidemos la fea palabra racial). Por su dignísima interpretación del alma popular, por su afán de redención, su emoción, su ironismo; por la expresión humanísima que agregó a la lírica continental, con su obra inconfundible, única.

Motivos del son (1930), Sóngoro cosongo (1931), West Indies Ltd. (1937) y Sones para turistas y soldados (1937) son las obras más difundidas de este autor. $\mathrm{El}$ tono folklórico de muchos de sus romances, lejos de aparecer como una simple valoración de tono documental, se aviva en una vibración intensa. Junto al sentido popular de lo más jugoso de su obra, debe subrayarse lo que ella tiene de recreación, de esencial depuración. Existen en Cuba poemas superiores a los de Guillén en colorido, en tropicalidad: bastaría recordar "La rumba" de Tallet. Pero Guillén es, sobre todo, quien ha dado, con mayor honestidad, con mayor fuerza, el sentido patético del negro 
y del mulato y del oprimido y desheredado de todas partes. $Y$ quien ha logrado más musicales y sugestivas estampas de antillanidad. $\mathrm{He}$ aquí una de ellas:

IYambambó, yambambé!

Repica el congo solongo, repica el negro bien negro;

congo solongo del Songo

baila yambó sobre un pie.

Mamatomba,

serembé cuserembá.

El negro canta y se ajuma,

el negro se ajuma y canta,

el negro canta y se va.

Acuememe serembó,

aé,

yambó,

aé.

Tamba, tamba, tamba,

tamba del negro que tumba;

tumba del negro, caramba,

caramba, que el negro tumba;

yamba, yambó, yambambé!

Guillén es también autor de un magnífico poema titulado "España", publicado en edición de gran formato, en México, 1937. Con el subtítulo de "poema en cuatro tragedias y una esperanza" ("Mirada de metales y de rocas"; "Tus venas, la raiz de nuestros árboles"; "Y mis huesos marchando en tus soldados"; y "Federico"), ese poema de tono sinfónico, de estremecidos versos, finaliza con "La voz esperanzada" (Una canción alegre flota en la lejanía) y se señala como uno de los más admirables cantos inspirados en el amor a España y al pueblo español, en su dolor y en la fe de su futuro amanecer. 


\title{
II. Manuel del Cabral
}

Pilón, el primer libro de Cabral, apareció en 1932, en su patria, con el subtítulo de "Cantos del terruño y otros poemas". No se trata, como en la mayoría de los casos, de una obra con los defectos inherentes a todo primer libro de versos, máxime teniendo en cuenta que el autor contaba entonces sólo veinticinco años de. edad. Pilón es un libro maduro, con personalidad, con nervio, rico de auténtica poesía. Muchos libros publicó después el autor. Su lirismo, dentro de su unidad, ha tomado diversos matices. $Y$, sin embargo, puede afirmarse que, en lo esencial, la individualidad es siempre la misma expresada en Pilón, que el artista ha ido ampliando, a medida que se extendía su visión de la vida y del arte. Es más: en su último libro Compadre Mon, editado en Buenos Aires en 1942, encontramos que sus tercetos fraternizan estrechamente con el primer poema de Pilón.

En el libro inicial de este dominicano valórase una interpretación muy auténtica del trópico de América, una de las pocas interpretaciones -en el plano lírico- purgadas de preciosismo, de falso romanticismo, de vano oropel. Su trópico es a la vez fino y fuerte, tal como to hallamos quienes to conocemos, quienes lo hemos viajado $y$ comprendido. He aquí uno de sus breves poemas: "Tierra adentro":

\author{
Trópico rabioso, \\ complicado y sencillo: \\ ihay que enlazarte como a los novillos! \\ Yo seré corazón en tu baraja, \\ y me daré tan limpio como el agua \\ de tu rural nevera: la tinaja. \\ Voy a buscarme tierra nacional; \\ tú me robaste, desde tus llanuras, \\ hasta la loma encinta $y$ desigual.
}

Telúrico, emotivo e imaginativo, Cabral sabe dar, en tres estrofas, el poema del alba en los campos dom:nicanos. $Y$ lo hace con visión nueva, con riqueza de detalles:

Nervioso el machete, su filo madruga saltando en el llano con gritos de sol. 
El es el barbero del viejo camino, del viejo camino que se trajo al agua hecha cabellera de verde mayot.

Las gallinas pintan sobre el suelo blando arañitas muertas al abrirse el día, mientras la pupila del molino acecha al Quijote viento de la serranía.

Ya cantando pila su maiz la negra. La mañana es oro sobre su pilón. Tejen por la calle su canción de rana los zapatos nuevos de la población.

¿Puede pedirse una mayor exactitud y originalidad en las imágenes? Cuanto más se lea estas estrofas, más se valorará al admirable poeta descriptivo que hay en su autor. En cierta manera, la finura y audacia de alguna imagen puede hacer evocar a los poetas simbolistas franceses y a quienes mejor los representan en nuestro idioma: el Lugones de Los doce gozos y el Herrera y Reissig de Los parques abandonados. Pero tal hermandad serviría únicamente para explicar la amplitud de la poética de Cabral, ya que su espíritu -americano- lo aparta, en esencia, de tal afinidad. Poeta moderno en la más noble acepción del vocablo, este dominicano sabe dar a su obra aquel carácter vasto en que entran todos los matices dignos de la lírica. $\mathrm{Y}$ así, en más de una de sus imágenes hallamos algo de la magia metafórica de los simbolistas. Ese es sólo uno de los aspectos que deben destacarse en su poliédrica obra. Por lo demás, la salud y el humanísimo acento de su poesía total impide que se le vincule a aquella escuela litéraria. Modalidades más avanzadas entran en su formación estética. $\mathrm{Y}$ del conjunto surge un poeta perșonalisimo, que no pertenece a ningún sector determinado, pues sabe fundir, en un crisol ancho, las experiencias propias y las ajenas, de donde resulta una obra tan interesante como intensa. Así, en su libro 8 gritos su lirismo toma sentido social. Y su expresión se hace más libre, tomando cierto aliento sinfónico. No se trata de esa poesía exasperada, con tono discursivo. Auténtico poeta, Cabral ha sabido dar jerarquía estética a sus gritos. Separamos de ellos, en nuestra predilección, el que dedica al "Negro de América", que se incorpora gallardamente a la poesía negra de nuestro Continente. Más que a Guillén, se asemeja a Langston Hughes en ese grito, que tiene -entre 
otros - el significado de ser como la síntesis de su óptima cosecha de poemas afroamericanos. He aquí "Negro de América":

A las doce de la noche brillan tus ojos de miedo, como dos velas pequeñas que van a velar tu entierro.

Negro de América:

te buscan

como a moneda falsa.

Y tu cansancio alumbra...

lo ilumina tu herida;

la herida

es lo único que sabe

mirar el horizonte

de par en par

abierto como un niño.

Negro de ayer,

inofensivo como tu amuleto

todavía misterioso

como la una de la noche de tu tambor,

y como los millones de años blancos

de tu cuerpo negro.

Juguete de los tiempos,

inédito do de pecho del sentido común.

Tu carne suda ciega...

amasarán tu sombra siglos de luz de sombra.

Por los hombres,

abres el barro de tus párpados

(tu barro es alcancía de caminos).

Ya no podrán comprarte las palabras

como te compran el sudor barato,

$y$ como te compraban

el luto eterno de tu carne.

Una fiebre de manos,

de manos que sudaron sacrificios:

aguardaron silencios bajo manos preñadas de oro,

frente a risas cargadas de vino,

frente a risas de bocas que dieron fallos obscuros. 
frente a hombres

huecos como la risa.

Negro de América:

el alba viene precoz,

viene anciana de claridad;

el alba que crece en los dedos heridos.

el alba que crece en las calles del Norte,

el alba del viento desnudo de tierra.

Tus manos,

tus manos

se van alargando lo mismo

que un nuevo camino...

La tierra,

la que vendrá mañana,

la tierra que tiene la arcilla del gesto,

la tierra que tiene la historia de tu piel.

Tu sangre ya nueva, vendrá como un tío que trae otros rios

y ensancha su vientre cargado de estrellas.

Esta veta de la poesía negra fué finamente explorada por Cabral. No sólo la de sentido social, sino también la canción breve y jugosa en su graficismo ("Música bárbara"), la alucinación de brujería ("Haitiano taumaturgo", "Rito negro") y esas cuartetas tan sintéticas, a manera de croquis estilizados y que se agrupan bajo el título de "Siete juguetes de barro". Y aún quedan más aspectos, que dan como total, una de las más humanas y artísticas interpretaciones de lo que el Caribe negro tiene de más típico, de más sustancial. Este poeta ha dedicado a ese tema dos libros: 12 poemas negros (editado en su patria, en 1935, y Trópico negro, publicado en Buenos Aires, seis años más tarde). En esta última obra aparecen algunos poemas de la primera, corregidos y ampliados por el autor. Es encomiable este velar en la obra, este trabajo de depuración. Cotejando la primera y la más reciente versión de algunos de los poemas negros de Cabral, puede estudiarse la evolución que la vida ha ido ejerciendo en su arte. Multiforme como la vida, su poesía ha pasado largos años sin tocar la inspiración de 12 poemas negros y de Trópico negro, pero el trópico y América han estado siempre en su visión. 
Sobre todo América, a veces sin trópico. $\mathrm{Y}$ ello ha sido una de las consecuencias de la vida viajera del poeta. En 1937 aparecía en Washington, en un cuaderno mimeografiado, su cuarto poemario publicado: Color de agua. Sonetos, canciones breves, a manera de tonadas, poemas de ritmo libre... Estrofas para niños, estrofas para adultos. ¿Qué linda ronda lírica! He aquí el "Juguete color de infancia":

Está listo y no se ve

tu coche color de brisa...

Es que la bruja te lee

la tacita de café:

un viaje

y una sonrisa

por equipaje.

Será tan linda y tan clara

la isla donde tú llegues

¡que será como tu cara!

-No grites, niña, ¿qué quieres?

la tierra entierra tu cielo,

niña, si tierra prefieres.

- Te voy a decir por qué

trajes de brisa te haré:

porque no quiero

que te vayas a quitar

tus zapatitos de sal.

Tal vez

no sepan andar

tus pies.

-No vayas al mar, y al mar

tras de tus ojos te vas.

-Mira tus manos: tus manos

no van a poder

volver...

que se te van a quedar,

por ser de nieve, en el mar... 
$Y$ al fin

te quedarás sin pensar,

lo mismo que tu muñeca

de aserrín.

Este lirismo tan moderno y en el que, al mismo tiempo, hay algo de vieja canción folklórica española - remozada por la estilización del poeta- inspira muchas de las páginas más musicales de Color de agua: "Croquis", "Juguete para los ojos" y esa deliciosa "Página de los poemas enanos".

Ha sido en Buenos Aires donde este dominicano ha publicado los dos libros que, en mi concepto, son los mejores de su dignísima obra: Biografía de un silencio (1940) y Compadre Mon (1942). En el primero de ellos aparece como resumido y exaltado todo lo que su lirismo tiene de fina simbología, de lenguaje denso y sutil, sin la maestría para describir el paisaje tropical, virtud esencial en Compadre Mon. Gabriela Mistral ha dicho - i y con cuánta razón! - que en Biografía de un silencio hay "poemas de gran categoría, poemazos de humanidad riquísima, y libres de imitación”. Ahí está el poema a Buenos Aires, extenso, sinfónico, trascendente; los "Cuatro poemas de infancia", de una emotividad tan penetrante; los originalisimos "Poemas para no ser cantados por los pájaros". Y, sobre todo, lo mejor del libro: el canto que le da el título general. Sus dieciséis páginas de apretada poesía serían más que suficientes —si la obra de Cabral no fuera tan rica- para darle el puesto de primera fila que le corresponde en el coro lírico de la América actual.

Compadre Mon es un canto dividido en 28 capítulos, o mejor, en 28 "tiempos". Está en casi su totalidad, versificado en tercetos endecasílabos, de rima consonante, sin la rigidez de los clásicos tercetos. $\mathrm{E} 1$ poeta ha dado a éstos una agilidad que va bien con el tema. Pues Compadre Mon es el elogio de la bravura criolla, de la reciedumbre americana, simbolizadas en un dominicano con algo de mito: el Compadre Mon, cuya fama de intrepidez encantó, como el mejor cuento, la niñez del poeta, en su región natal. $\mathrm{Y}$ nuevamente nos enfrentamos con un trópico fuerte, distinto de aquél, ampuloso, lánguido y enfático a la vez, que tanto ha pregonado y dañado cierta literatura fofa. Compadre Mon recuerda, por su forma, al primer poema del primer libro de este dominicano. Allí decía Cabral: 
Es tan pequeño, Patria, tu terruño, alto de azules $y$ ancho de sabanas, que me parece cabes en un puño.

$\mathrm{Y}$ en Compadre Mon, diez años más tarde:

Como frente a una carta de raíces, para saber el mapa de la tierra yo me puse a leer tus cicatrices.

En Compadre Mon, lo épico y lo lírico se funden en una armonía originalísima, en que la línea severa del poema clásico aparece como ductilizada por la expresión novísima, plena de hallazgos, de imágenes inéditas, de epítetos remozados y revalorizados. $\mathrm{Y}$ esos 28 cantos que forman el poema son los que mejor merecen los conceptos que Domingo Moreno Jiménez - uno de los más altos valores de la cultura dominicana - dedicó a la poesía de. Manuel del Cabral: "Las campanas del arte americano suenan a alba con estos cantos."

Gastón Figueira, Montevideo. 
